INDEPENDENT JOURNAL OF MANAGEMENT \& PRODUCTION (IJM\&P)

http://www.ijmp.jor.br

v. 12, n. 8, November-December 2021

ISSN: 2236-269X

DOI: 10.14807/ijmp.v12i8.957

\title{
HEALTHY LUNGS MAINTAIN A YOUNG AND ENERGETIC BODY
}

Florian Ion Tiberiu Petrescu

IFToMM, Romania

E-mail: fitpetrescu@gmail.com

Relly Victoria Virgil Petrescu

IFToMM, Romania

E-mail: rvvpetrescu@gmail.com

Submission: $1 / 4 / 2019$

Revision: $11 / 24 / 2020$

Accept: 12/1/2020

\section{ABSTRACT}

In general, life is only possible in the presence of oxygen in a form that can be easily absorbed by the body. In the case of humans, the lungs have as their main task the provision of the oxygen necessary for the body to carry out daily activities. The lung is a paired organ located in the chest cavity, a fibro-elastic organ capable of altering your volume during breathing (inspire and expire). The weight of a lung varies between 800 and 1,000 grams, of which more than 50\% is blood. The air reaches the lungs through a pipeline system consisting of Nazopharynx, larynx, trachea, bronchi, and bronchiole. The role of the piping system is to heat and dampen the air or to capture and remove foreign inhaled particles. The channel system decreases in diameter after each branch - from the trachea and the large bronchi to the bronchiole with a diameter of less than one millimeter. The lung consists of over 30 different cell types. Trachea and large bronchi are taped by a mucous layer containing multiple cell types: ciliary cells - provides mucus movement, caliciform cells - secretes mucus, basal cells - plays a role in regeneration and neuro-ectodermic cells - ensures the secretory function of the lungs. In the chorion (the deep layer beneath the mucosa) there are cells involved in the defense processes - lymphocytes, mast cells, eosinophils or neutrophils.

Keywords: Human body; Human body's lungs; Physiopathology; Anti-aging 
DOI: 10.14807/ijmp.v12i8.957

\section{INTRODUCTION}

In general, life is only possible in the presence of oxygen in a form that can be easily absorbed by the body. In the case of humans, the lungs have as their main task the provision of the oxygen necessary for the body to carry out daily activities.

The lung is a paired organ located in the chest cavity, a fibro-elastic organ capable of altering your volume during breathing (inspire and expire). The weight of a lung varies between 800 and 1,000 grams, of which more than $50 \%$ is blood.

The lung develops gradually during intra-uterine life. During the first month of pregnancy, there are two bronchial buds that will develop in the primary bronchi. Then every week these buds will divide, reaching 28 generations (branching) of the bronchi - the next bronchial tree after 28 weeks. After birth the number of alveoli increases (up to the age of 3 years), then matures functionally, becoming mature alveoli (up to the age of 8).

The lungs are the main organs of breathing. There are two lungs (lance and right) located in the chest cavity, each covered by visceral pleura. The lungs have the form of half a cone. Their color varies with age; to the fetus, red-brown, to the gray-to-gray child, to the darker adult more or less closed. The weight of the lungs is $700 \mathrm{~g}$ for the right lung and $600 \mathrm{~g}$ for the left lung.

The total lung capacity is $5000 \mathrm{~cm}^{3}$ aer. Total lung consistency is classic, sponge. The vertical diameters are $22 \mathrm{~cm}$, anteroposterior to the base of $18-20 \mathrm{~cm}$ and transversally at the base of $9-10 \mathrm{~cm}$. (The right diameter of the lung is smaller than the left, but the other diameters are larger).

The external face of the lungs is convex and comes in relation to the ribs. On this face, there are deep ditches called scree, which distribute the lungs in the lobes. On the external face of the right lung, there are two skulls - one oblique (main) and another horizontal, which begins at the middle of the oblique fission. These two scions divide the lungs into three lobes (upper, middle and lower). On the external face of the left lung, there is a single fissure (oblique fissure), which divides the left lung into two lobes (upper and lower).

The side face is flat and comes in contact with the mediastinal organs. On this face, closer to the posterior edge of the lungs, there is the pulmonary hill where the vessels, the nerves, and the main bronchus enter or leave the lung. 
DOI: 10.14807/ijmp.v12i8.957

The base of the lungs is concave and comes in relation to the diaphragm. The tip of the lung lifts up the first coast and comes in relation to the organs at the base of the neck. The anterior sharp edge is located behind the sternum, and the posterior, rounded, is in relation to the backbone and posterior extremity of the ribs.

The air reaches the lungs through a pipeline system consisting of Nazo-pharynx, larynx, trachea, bronchi, and bronchiole.

The role of the piping system is to heat and dampen the air or to capture and remove foreign inhaled particles.

The channel system decreases in diameter after each branch - from the trachea and the large bronchi to the bronchiole with a diameter of less than one millimeter (Aversa et al., 2018ab, 2017a-b, 2016a-n; Aljohani \& Desai, 2018; Alexander \& Wang, 2018; Apicella et al., 2018 a-c; Marquetti \& Desai, 2018; Armah, 2018; Wilk et al., 2017; Babaev et al., 2010; Buzea et al., 2015; Petrescu et al., 2015; Petrescu, 2008-2009; Abdul-Razzak et al., 2012; Ajith et al., 2009; Atasayar et al., 2009; Ahmed et al., 2011; Covic et al., 2007; Willis, 1953-1954, 1957; Ha, 2010; El-Gendy, 2009; Enstrom, 2014; Hansen, 2014; Rath, 1990, 2003; Yilmaz, 2006; Ravnskov, 2009; Kunutsor, 2016; Hickey, 2007; Choudhury \& Greene, 2018; Choudhury, 2018).

\section{METHODS AND MATERIALS; THE STRUCTURE OF THE LUNGS AND FUNCTIONALITY}

The lungs consist of: the bronchial tree, the lobules (pyramidal formations located at the last branches of the bronchial tree), the branches of the pulmonary and bronchial vessels, nerves and lymph, all contained in connective tissue.

The bronchial tree.

The main bronchus, penetrating into the lung through the hill, is divided intrapulmonary to the right in three lobar bronchi (upper, middle and inferior), and to the left in two lobar bronchi (upper and lower).

The lobar bones then divide into segmental bronchi that provide aeration of the bronchopulmonary segments (anatomical and pathological units of the lungs). They have their own limitations, aeration, vascularization, and pathology. The right lung has 10 segments, the left 9. 
DOI: 10.14807/ijmp.v12i8.957

Segmental bronchi are divided into lobular bronchiole which serves the pulmonary lobules, the morphological units of the lung, the pyramidal form, with the base to the periphery of the lung and the peak to the hill.

The lobular bronchiole, in turn, branches into the respiratory bronchiole from which the alveolar ducts are terminated by alveolar sacs.

The walls of the alveolar sachets are compartmentalized into the lung alveoli.

Respiratory bronchi, together with the formations derived from them (alveolar ducts, alveolar sacs, and pulmonary alveoli) form pulmonary acinus. Acin is the morpho-functional unit of the lung.

The structure of the bronchial tree also changes. Lobar bronchi have a structure similar to the main bronchi. Segmental bronchial also have a cartilaginous skeleton fragmented (cartilage islands), instead, the lobular and respiratory lobes completely lose cartilaginous skeleton.

The lobular and respiratory bronchioles have a fibro-elastic wall over which smooth muscle fibers are disposed. In the alveolar duct walls, we encounter only the fibro-elastic membrane lined with epithelium.

The pulmonary alveoli are in the form of a small, extremely thin sachet adapted to gaseous exchanges. On a fibro-elastic membrane, there is an alveolar epithelium with a double function: phagocytic and respiratory.

There are about 75-100 million alveoli, with an area of 80-120 m².

A rich perialveolar capillary network is found around the alveoli, which together with the alveolar walls form the alveolar-capillary barrier, in which structure we mention the alveolar epithelium, the basal fibro-elastic membrane of the alveoli, the basal membrane of the capillary and capillary endothelium. At the level of this barrier, there are gas exchanges between the alveoli and the blood.

The lung consists of over 30 different cell types. Trachea and large bronchi are taped by a mucous layer containing multiple cell types: ciliary cells - provides mucus movement, caliciform cells - secretes mucus, basal cells - plays a role in regeneration and neuro-ectodermic cells - ensures the secretory function of the lungs. In the chorion (the deep layer beneath the mucosa) there are cells involved in the defense processes - lymphocytes, mast cells, eosinophils 
or neutrophils. Respiratory bronchiole and terminal channels (the last ramifications of the bronchial tree, open in alveolar bags) contain Clara cells - secret surfactant and mucus (Fig. 1).

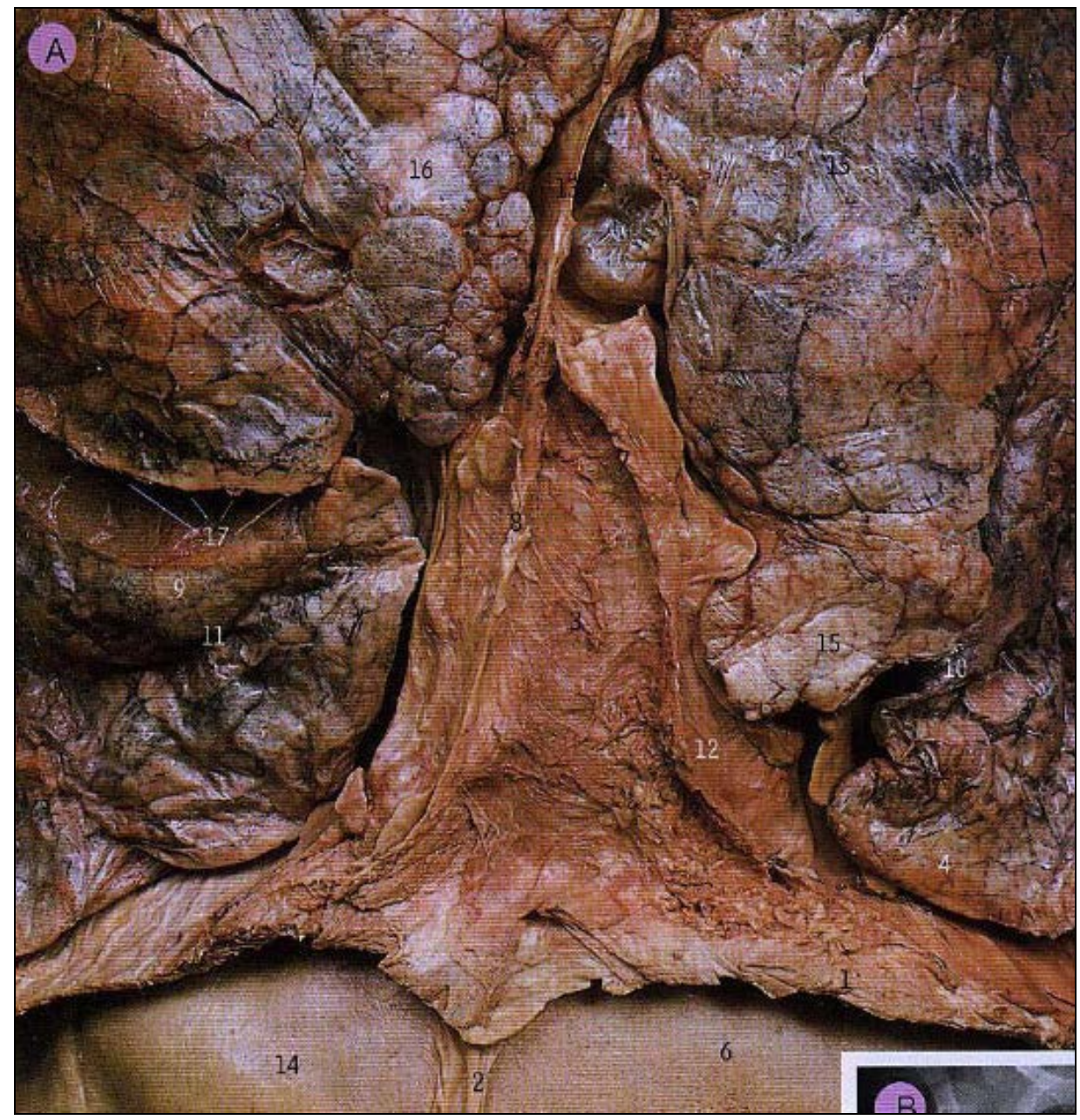

Figure 1: The structure of the lungs

Source: https://www.scientia.ro/images/stories/articles/2012/aprilie/17/plamani_1.jpg

1-aperture; 2-falciform ligament; 3-fibrous pericardium; 4-lower lobe of the left lung; 5-lower lobe of the right lung; 6-the left liver lobe; 7-line of the left pleura reflection; 8-line of the right pleura reflection; 9-middle lobe of the right lung; 10-fissure oblique; 11-oblique fissure of the right lung; 12-pleura covering the pericardium; 13-left and right pleura in contact; 14-the right liver lobe; 15-the upper lobe of the left lung; 16-the upper lobe of the right lung; 17-the transversal fissure of the right lung.

\subsection{Vascularization of the lungs}

The lungs have a double vasculature: nutritional and functional.

1) Nutritional vascularisation is provided by the bronchial arteries, branches of the thoracic aorta, which bring oxygen to the blood. The bronchial arteries enter the lung through the hill and accompany the bronchial shaft, reaching only to the respiratory bronchiole, ending in the capillary network, from which the bronchial veins that carry the blood with CO2 in the azygos system start, ending in the superior cava. Nutritional vascularization of the lung makes the circulation large. 
DOI: 10.14807/ijmp.v12i8.957

2) Functional vasculature belongs to small circulation. It begins with the pulmonary trunk that originates in the right ventricle. The lung trunk brings blood loaded with CO2 to the lung. After a short tract, it splits into the left and right pulmonary artery, each penetrating the lung through the hill. In the lung, the pulmonary arteries divide into branches that accompany the branches of the bronchial shaft up to around the alveoli, where they form the perialveolar capillary network. At this level, the blood yields CO2 and gets O2. From the capillary network, the pulmonary veins start (two for each lung). They come out of the lung through the hill and go to the left atrium.

Because the vascularization of the lungs is dual - nutritional and functional, the nutritional is provided by the bronchial arteries, while the functional one is the pulmonary artery (small circulation).

Functional vasculature starts from the right ventricle - the pulmonary artery, with nonoxygenated blood. It splits into two branches for each lung and branches up to the formation of a pulmonary capillary network (very small diameter vessels). The main role of the capillary network is to participate in the exchange of gas between air and blood. All branches of the mesh unite and form the pulmonary veins (they carry oxygenated blood) that flow into the left atrium.

The functional unit of the lung is the pulmonary acin (or alveolar sac) made up of pulmonary alveoli. They contain two types of cells - type I pneumocytes and type II pneumocystis (the second type of surfactant). In addition to these cells, macrophages can also be found. In total, the two lungs contain approximately 300 million lung alveoli that provide for the exchange of respiratory gas between the blood and the atmospheric air. The main role in this exchange lies with the alveolar membrane. This is an air-blood barrier consisting of type I and II pneumocytes and surfactant in the alveolar part, and on the other side of the membrane and capillary endothelium.

The thickness of the membrane is only 0.5 micrometers and ensures rapid gas exchange (between blood and air). The surfactant I have mentioned is a fluid whose role can be easily understood - compare the pulmonary alveolus with a rhythmically inflamed rubber bubble (respiratory movements), and the surfactant that holds the alveolus open with the talcum powder inside the balloon prevents the rubber from sticking. So, the role of the surfactant is to prevent collapsing the pulmonary alveolus. 
DOI: 10.14807/ijmp.v12i8.957

The lungs are covered by a membrane - the pleura (Fig. 2). It consists of two foils, a visceral one that adheres to the surface of the pulmonus and a parietal one that adheres to the chest wall. Between the two sheets there is an amount of fluid that plays a role in the respiratory movements. The amount of fluid that is found between the pleura leaves is $15 \mathrm{ml}$, but within 24 hours $600 \mathrm{ml}$ of fluid is secreted, which means that the pleural fluid is renewed several times in a single day.

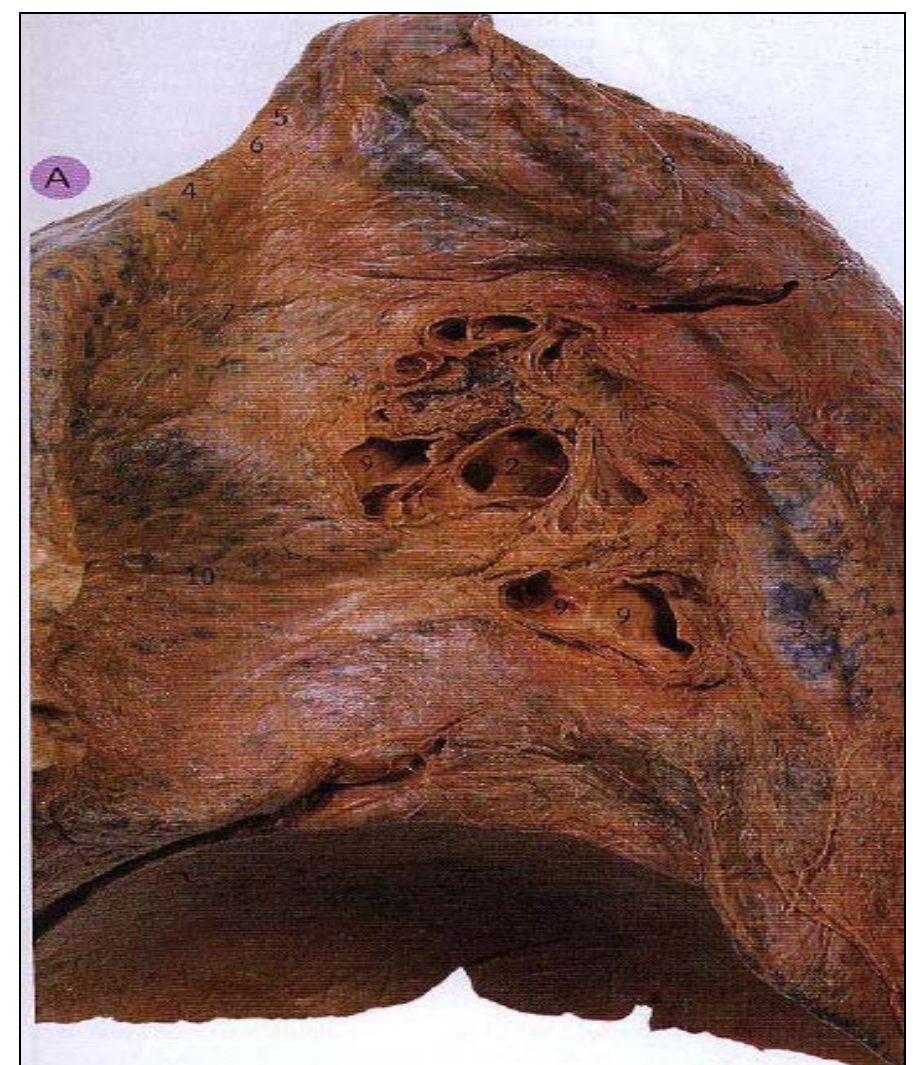

Figure 2: Pleura is a membrane covering the lungs to protect them.

Source: https://www.scientia.ro/images/stories/articles/2012/aprilie/17/plamani_2.jpg

1-branches of the main right bronchus; 2-branches of the right pulmonary artery; 3-seam of the azygos vein; 4seam of the first rib; 5-seam for subclavian artery; 6-subclavian vein ditch; 7-seam for superior cava vein; 8esophageal aria and trachea; 9-pulmonary right veins; 10 -fissure transverse.

Pulmonary ventilation is a dynamic process that ensures air penetration into the airways. Inspiration (air intake) is an active, energy-consuming process, carried out by the contraction of the inspiring muscles that increase the volume of the chest. The lung follows faithfully the movements of the chest. Exhale - a passive process, is achieved by relaxing the respiratory muscles, which leads to a decrease in the volume of the chest.

The air penetrates into the lungs due to differences in pressure between atmospheric air and air in the lungs. The speed of movement in the airways is $30 \mathrm{~cm} / \mathrm{sec}$ and decreases to 0 in the alveoli. Of the inspired air volume, only two-thirds participate in gaseous exchanges, the rest remains on the trachea or in the bronchi (a dead functional space). 
DOI: 10.14807/ijmp.v12i8.957

Respiratory volumes can be measured with an apparatus called spirograph. It measures vital capacity (CV) - consisting of current volume (VC), spare inspiratory volume (VIR), and spare expiratory volume (VER).

VC - is the volume of air that penetrates into the lungs during normal, resting respiration. This is $500 \mathrm{ml}$ of air, out of which only $350 \mathrm{ml}$ reach the territories where gas exchanges are made.

VIR - is the maximum volume of air that can be inserted into the lungs after a normal inspiration. Its value is $1200-1,500 \mathrm{ml}$ of air and together with VC forms the inspiratory capacity of the lung (CI).

VER - is the maximum volume of air that can be removed from the lung after a normal exhalation and is $1200 \mathrm{ml}$.

In addition to these volumes, there is also the residual volume (VR). VR is the volume of air that is always in the lungs and can not be removed, just renewed. The VR is $1200 \mathrm{ml}$ and together with the $\mathrm{CV}$ form the total pulmonary capacity (CPT). Residual volume is of great importance in legal medicine. With the help of residual volume, it can be determined whether a child was born dead or died after birth - VR penetrates into the lungs after the first breath. If the baby is born dead his lungs will not float in the water, but if he breathes after birth, the lungs will remain at the surface of the water.

Breathing is a complex process consisting of three phases - pulmonary respiration, airway transport, and cellular respiration (cell-to-blood gas exchange).

Alveolocapillary membrane gas changes (pulmonary respiration) are governed by the physical laws of diffusion - the Boyle-Mariotte law (gas pressure at the same temperature is inversely proportional to volume), the Gay-Lussac law (the volume of a gas increases once with temperature if the pressure remains constant).

The consequence of pulmonary ventilation is the permanent intake of oxygen. Oxygen arrived in the pulmonary alveolar is absorbed into the capillary blood. One minute passes 200 $\mathrm{ml}$ of oxygen from the alveolar air into the capillary blood.

Due to metabolic processes in the human body, large amounts of acids are produced. Non-volatile acids are eliminated through the kidneys, and volatile ones are eliminated through the lungs - CO2. It will be permanently removed externally through the ventilation process. The rate of carbon dioxide removal is $200 \mathrm{ml}$ per minute. 
DOI: 10.14807/ijmp.v12i8.957

Breathing is a nervous and humorous process. Although it can be controlled voluntarily, breathing is regulated by reflex and humorous mechanisms - you cannot kill yourself if you keep your breath. Breathing is regulated by the respiratory centers located in the brain.

In addition to nervous centers, there are a number of mechanisms that regulate breathing. These are the pressure receptors. They respond to changes in blood pressure (baroreceptors) or respiratory gases (chemoreceptors).

The lung, like most organs, has a major function - respiratory function, but also other side functions: antitoxic, metabolic or depot function.

\subsection{Antitoxic function}

By inhalation are inhaled particles that can harm the body: powders, bacteria, toxic gases. Particles with a larger diameter are retained in the mucus of the trachea or bronchi, but those with a small diameter - less than 3 micrometers, reach the pulmonary alveoli. All particles suspended by the mucus are removed with it through the movements of the cilia. In addition to ciliary transport, the reflex of a cough and sneezing intervenes, which contributes to the elimination of contaminated secretions.

Particles in the alveoli are phagocytic by macrophages. Those that get rid of macrophages are in contact with the surfactant in the alveoli. It contains enzymes (lysozyme, esterase), interferon or Ig A antibodies that destroy bacteria and prevent colonization of the alveoli (sterile areas normally).

In addition to protecting the body from bacteria, the lungs can remove some toxins from the body. These are volatile substances that easily pass through the alveolar-capillary membrane - it produces a breathing halo. This can remove alcohol, urea, and nitrous oxide.

\subsection{Metabolic function and immune function of the lungs}

The lung is involved in glucose, lipid, protein metabolism and in the metabolism of some hormones or chemical mediators. The lung determines the conversion of angiotensin I to angiotensin II - a substance with strong vasoconstriction effects. Lungs synthesize a wide range of substances with different effects in the body - prostacyclin, thromboxanes or leukotrienes.

Later, it was found that the lungs produced various types of leukocyte cells needed to protect the body, thereby enhancing immune function.

\subsection{Accessories features}


DOI: 10.14807/ijmp.v12i8.957

The lungs can store up to $12 \%$ of the body's blood volume under resting conditions the blood vessel function, which they send in circulation when needed. In addition to the storage function, the lungs are also involved in maintaining the hydro-electrolytic balance. They can remove large amounts of water, heat and carbon dioxide.

Together with the bone system and the liver, the lungs are true tanks of blood, can keep a large amount for an unlimited, shorter or a very long time after the needs of the body. The same is done for the liver, but only for short periods of time for certain blood vessels. Bones that produce blood in their marrow can store large amounts of blood, and can also regenerate it so that the lungs form alongside the bone system in a true blood-capacitor reservoir, absolutely necessary for the human body. When the amount of blood and water in the body decreases, the body begins to age and lose energy from water and transported through the blood. In order to delay the human aging process, it is therefore absolutely necessary to keep both lungs healthy at maximum functional capacity as well as the bone system for a long time in our lives.

\section{RESULTS AND DISCUSSION}

Breathing is the exchange of $\mathrm{O} 2$ and $\mathrm{CO} 2$ between the body and the environment. This exchange takes place in three stages:

- pulmonary stage - external breathing

- blood stage - gas transport

- Tissue Stage - External Breath

True breathing, in the strict sense of the word, is the tissue, while the first two stages only provide the breathing of the breathing gases from the internal environment.

\subsection{The pulmonary stage realizes the first moment of gaseous exchanges.}

In the alveolar-capillary membrane, $\mathrm{O} 2$ passes from the alveolar air into the blood, and $\mathrm{CO} 2$ in the opposite direction. The organs of external breathing are the lungs and chest (passive organs) and respiratory muscles (active organs).

Respiratory movements occur as a result of the rhythmic intake and outflow of respiratory muscles. These movements take place in two phases: inspiration and expiration.

Inspiration is an active process through which atmospheric air penetrates the lungs. The main inspiring muscle is the diaphragm. By contraction, the diaphragm descends flattens and 
DOI: 10.14807/ijmp.v12i8.957

increases the vertical diameter of the chest box. Apart from the diaphragm, inspiration is also produced by external intercostal muscles.

Expiration is the act by which the air leaves the lungs. The only muscles involved in the expiration are internal intercostals.

The two phases of pulmonary respiration are successively performed without a break with a resting frequency of 14-16 cycles/minute in the man and 18 breaths per minute in a woman.

Neuro-moral regulation of lung breathing

By regulating breathing, it is commonly understood to regulate fan movements and fan flow.

\subsection{Fan flow rates vary by frequency and amplitude of respiratory movements}

The nervous regulation of ventilation is achieved by the intervention of the respiratory centers. They provide automatic breathing control.

There are primary respiratory centers located in the bulb and accessory respiratory centers located at the deck level, represented by the 2/3 hindpaw center and the pneumotoxic center of the previous $1 / 3$.

The activity of bulb-pontin nervous centers is altered both in intensity and frequency, under nerve and humoral influences.

Nervous influences can be of two kinds:

- direct, encephalic nerve centers or other neighboring centers;

- reflexes, from receptors spread throughout the body.

Direct cortical nerve influences allow voluntary control of ventilator movements within certain limits. They explain changes in breathing in emotional states as well as respiratory conditional reflexes.

Hypothalamic centers alter the frequency of breathing according to ambient temperature.

Reflex influences can come from the totality of intero-, extero- and proprioceptors in the body. 
DOI: 10.14807/ijmp.v12i8.957

The main respiratory reflexes are initiated at the level of the respiratory and cardiovascular devices.

The humorous regulation of breathing is due to the influences exerted on the respiratory centers by a number of substances. The most important role in the humoral regulation of breathing plays the breathing gases $\mathrm{CO} 2$ and $\mathrm{O} 2$.

The essential role of $\mathrm{CO} 2$ and therefore this substance has been called respiratory hormone. It acts directly on the centers. The increase in PCO2 in arterial blood only by $0.6 \mathrm{~mm}$ $\mathrm{HgC}$ from 40 to 40.5) is followed by doubling the pulmonary ventilator flow rate (from 8 to 16 l / min). Decreasing PCO2 causes breathing and even stopping it (apnea).

The role of $\mathrm{O} 2$ is also important. The increase in PO2 in arterial blood excites the chemoreceptors of the reflexogenic regions causing hyperventilation. The decrease in PO2 acts directly on the centers, but its chemo-reflexive effects are more important.

\subsection{Blood stage transports $\mathrm{O} 2$ and $\mathrm{CO} 2$ through blood.}

$\mathrm{O} 2$ transport is from the lung to lung tissue $\mathrm{O} 2$ diffuses from alveolar air where its partial pressure is $100 \mathrm{~mm} \mathrm{Hg}$ in venous blood where PO2 is $40 \mathrm{~mm} \mathrm{Hg}$.

O2 transport forms are: physically dissolved in the plasma (0.3 O2\%) and chemically rich in the form of oxyhemoglobin (HbO2) in the proportion of $20 \mathrm{O} 2 \%$ blood.

CO2 transport is made from tissues to the lungs. Carbon dioxide diffuses from tissues where PCO2 is $46 \mathrm{~mm} \mathrm{Hg}$ to arterial blood where PCO2 is 40.

The forms of CO2 transport are:

- $\quad$ physically dissolved in the plasma as carbonic acid in a proportion of $3 \mathrm{~cm}^{3 \%} \%$;

- chemically bound in the form of $60-60 \%$ Na-bicarbonate in plasma;

- chemically bound to plasma proteins, $\mathrm{Hb}$ and K-bicarbonate in erythrocytes;

\subsection{Tissue Stage - Internal Breath}

It is the actual breath of body cells. This process essentially consists of oxidationreduction reactions during which hydrogen is combined with oxygen to give the water and chemical energy that underlies cellular life.

\subsubsection{Sleep apnea syndrome (apnea $=$ breathing disorder)}


DOI: 10.14807/ijmp.v12i8.957

Sleep apnea syndrome (SAS) is a respiratory disorder characterized by frequent and long breaks of sleep during sleep. Sleep normally causes hypoventilation and episodes of apnea, but these do not last for more than 10 seconds.

SAS occurs due to the decrease in diameter in the upper airways (pharynx). These sick people snore, but when apnea occurs, snoring stops for up to 90 seconds. During all this time severe hypoxia occurs and the patient wakes up. After a few seconds, the patient is resting. But apnea episodes appear at a higher frequency of 200 per night (6-7 hours), making sleep difficult.

The consequences of SAS are Excessive drowsiness (these patients will never wake up), memory loss and concentration disorder, high blood pressure and increased risk of myocardial infarction and stroke.

\subsubsection{Respiratory insufficiency.}

a) 2 large types, hypoxemic (I) and hypercapnia (II)

- Acute (acidosis), chronic (pH N)

- Diagnosis: Gasometer

- Treatment:

- Airways, Breath, Circulation;

- Controlled Oxygenotherapy (Attention to the

- hypercapnia!), ventilation (non-invasive - invasive)

- Treatment and causes

- Disturbance of gas exchange at the level

b) alveolar-capillary

- Decreases $\mathrm{PaO} 2$ below normal value $=$ HIPOXEMIA

- Can increase PaCO2 = concomitantly = hipercarbie

c) Hypoxemia

- Normal values - age, oxygen in the air

- inspired, atmospheric pressure, temperature 
DOI: 10.14807/ijmp.v12i8.957

- $\quad \mathrm{PaO} 2=100.1-0.323$ (age in years) $\pm 5 \mathrm{mmHg}$

o $\quad$ Normal $=95-96 \mathrm{mmHg}$

o Arterial saturation $=96 \%$

d) Hypoxemia

- $\quad$ Light $-60-95 \mathrm{mmHg} \pm 5 \mathrm{mmHg}$

- Respiratory insufficiency

o Moderate $-45-60 \mathrm{mmHg} \pm 5 \mathrm{mmHg}$

o Severe - below $45 \pm 5 \mathrm{mmHg}$

e) Hypercapnia

- Not influenced by environmental or environmental parameters age

- $\quad$ Normal $=35-45 \mathrm{mmHg}$

- Respiratory insufficiency

o $\quad$ PaCO2 above $50 \mathrm{mmHg}$

f) General respiratory insufficiency

- IR is not a disease, but a functional disorder

- determined by various pathological causes

- Diagnosis is exclusively laboratory (PaO2, $\mathrm{PaCO} 2)$

- Clinical appearance can accurately suggest the presence of IR but is not sufficient in the absence of laboratory tests

o Cardiac insufficiency - Clinically

o Renal insufficiency - laboratory

\subsubsection{Acute respiratory insufficiency}

a) etiology:

- Depression of the respiratory center

o Overdose of drugs (opioids), intoxications

o They were SNCs 
DOI: 10.14807/ijmp.v12i8.957

o Unconsciousness

o Progressive oxygen therapy in patients with chronic hypoventilation

- Lack of transmission of nerve impulses to mm respirators

o Marrow damage

o Myelitis

o Infections (tetanus, polio, botulism)

o Neuromuscular diseases (myasthenia gravis, motor neuron diseases, muscular dystrophies):

- chronic hypoventilation with acute exacerbation, e.g. respiratory infection

o Polyradiculitis

- Impact of ventilator mechanics

o Chest trauma, diaphragm rupture

o Pneumothorax with valve, hemothorax

o Severe kyphoscoliosis (usually chronic hypoventilation with acute exacerbation, eg infection respiratory)

For centuries, traditional medicine systems around the world have used plants to treat respiratory diseases.

Even modern studies have recognized the efficacy of a plant in treating respiratory diseases, repairing lung damage, and improving lung function.

They can be used as alternatives to drugs to solve lung problems. Here are some plants that will clean your lungs and treat respiratory diseases:

b) Thyme

It is very strong in the fight against chest congestion. This plant produces powerful antiseptic essential oils, considered a natural and antifungal antibiotic.

Thyme also works against acne, making it more effective than expensive creams and gels. 
DOI: 10.14807/ijmp.v12i8.957

Thyme tea has the power to eliminate bacteria and viruses, being a natural remedy used since antiquity to prevent and treat respiratory tract infections.

c) Oregano

Although oregano contains vitamins and nutrients for immunity, its primary benefits are carvacrol and rosmarinic acid.

These compounds are naturally decongestant and reduce histamine, having positive effects on the respiratory tract.

Oregano oil fights against dangerous bacteria such as golden Staphylococcus, better than the most powerful antibiotics.

d) Eucalyptus

Originally from Australia, eucalyptus is not just for Koala bears! Aborigines, Germans, and Americans use the eucalyptus refreshing aroma for respiratory ailments and calming throat irritation. Eucalyptus contains cineol which has many advantages: it is expectorant, helps relieve cough and congestion and soothes irritated sinuses.

Eucalyptus also contains antioxidants that help the immune system during colds and infections.

e) Sage

The leaves of sage emanate a strong flavor, resulting in essential oils. These oils have multiple benefits for lung problems - cough, sore throat and sinusitis.

Sage tea is a traditional remedy for a sore throat and cough. It can be administered internally or externally by inhalation.

f) Leaves of Patagonia

They have been used for hundreds of years to soothe a cough and mucous irritation.

Leaves of Patagonia has antibacterial and anti-microbial, anti-inflammatory and antitoxic properties.

According to the studies, the Leaves of Patagonia is favorable against a pulmonary cough, colds, and irritations. It improves a dry cough and reduces the mucus in the lungs.

g) Mint 
DOI: 10.14807/ijmp.v12i8.957

Mint and peppermint oil contain menthol - a soothing ingredient known to relax the muscles of the respiratory tract, decongestant, and a powerful antioxidant.

The plant that keeps your lungs healthy and gets rid of coughs

h) Honey of the bear

Bear's honey is a lichen that resembles lung tissue. Since 1600, the bear's honey has been used to treat respiratory and lung problems. Bear's honey contains compounds that are effective for lung health.

i) Mullet (the candle plant)

Both flowers and candle leaves are used to prepare an extract that helps to strengthen the lungs. The candle is used to reduce excess mucus from the lungs, cleans bronchial tubes and reduces inflammation in the respiratory tract. Tea can be made from a teaspoon of dried herb to a cup of boiled water. Alternatively, you can take candy tincture.

Onions and garlic remain two main active remedies for permanent maintenance of the lungs.

\section{CONCLUSIONS}

In general, life is only possible in the presence of oxygen in a form that can be easily absorbed by the body. In the case of humans, the lungs have as their main task the provision of the oxygen necessary for the body to carry out daily activities.

The lung is a paired organ located in the chest cavity, a fibro-elastic organ capable of altering your volume during breathing (inspire and expire). The weight of a lung varies between 800 and 1,000 grams, of which more than $50 \%$ is blood.

The lung develops gradually during intra-uterine life. During the first month of pregnancy, there are two bronchial buds that will develop in the primary bronchi. Then every week these buds will divide, reaching 28 generations (branching) of the bronchi - the next bronchial tree after 28 weeks. After birth the number of alveoli increases (up to the age of 3 years), then matures functionally, becoming mature alveoli (up to the age of 8).

The lungs are the main organs of breathing. There are two lungs (lance and right) located in the chest cavity, each covered by visceral pleura. The lungs have the form of half a cone. Their color varies with age; to the fetus, red-brown, to the gray-to-gray child, to the 
DOI: 10.14807/ijmp.v12i8.957

darker adult more or less closed. The weight of the lungs is $700 \mathrm{~g}$ for the right lung and $600 \mathrm{~g}$ for the left lung.

The total lung capacity is $5000 \mathrm{~cm}^{3} \mathrm{aer}$. Total lung consistency is classic, sponge. The vertical diameters are $22 \mathrm{~cm}$, anteroposterior to the base of $18-20 \mathrm{~cm}$ and transversally at the base of $9-10 \mathrm{~cm}$. (The right diameter of the lung is smaller than the left, but the other diameters are larger).

The external face of the lungs is convex and comes in relation to the ribs. On this face, there are deep ditches called scree, which distribute the lungs in the lobes. On the external face of the right lung, there are two skulls - one oblique (main) and another horizontal, which begins at the middle of the oblique fission. These two scions divide the lungs into three lobes (upper, middle and lower). On the external face of the left lung, there is a single fissure (oblique fissure), which divides the left lung into two lobes (upper and lower).

The side face is flat and comes in contact with the mediastinal organs. On this face, closer to the posterior edge of the lungs, there is the pulmonary hill where the vessels, the nerves, and the main bronchus enter or leave the lung.

The base of the lungs is concave and comes in relation to the diaphragm. The tip of the lung lifts up the first coast and comes in relation to the organs at the base of the neck. The anterior sharp edge is located behind the sternum, and the posterior, rounded, is in relation to the backbone and posterior extremity of the ribs.

The lung, like most organs, has a major function - respiratory function, but also other side functions: antitoxic, metabolic or depot function.

By inhalation are inhaled particles that can harm the body: powders, bacteria, toxic gases. Particles with a larger diameter are retained in the mucus of the trachea or bronchi, but those with a small diameter - less than 3 micrometers, reach the pulmonary alveoli. All particles suspended by the mucus are removed with it through the movements of the cilia. In addition to ciliary transport, the reflex of a cough and sneezing intervenes, which contributes to the elimination of contaminated secretions.

Particles in the alveoli are phagocytic by macrophages. Those that get rid of macrophages are in contact with the surfactant in the alveoli. It contains enzymes (lysozyme, esterase), interferon or Ig A antibodies that destroy bacteria and prevent colonization of the alveoli (sterile areas normally). 
DOI: 10.14807/ijmp.v12i8.957

In addition to protecting the body from bacteria, the lungs can remove some toxins from the body. These are volatile substances that easily pass through the alveolar-capillary membrane - it produces a breathing halo. This can remove alcohol, urea, and nitrous oxide.

The lung is involved in glucose, lipid, protein metabolism and in the metabolism of some hormones or chemical mediators. The lung determines the conversion of angiotensin I to angiotensin II - a substance with strong vasoconstriction effects. Lungs synthesize a wide range of substances with different effects in the body - prostacyclin, thromboxanes or leukotrienes.

Later, it was found that the lungs produced various types of leukocyte cells needed to protect the body, thereby enhancing immune function.

The lungs can store up to $12 \%$ of the body's blood volume under resting conditions the blood vessel function, which they send in circulation when needed. In addition to the storage function, the lungs are also involved in maintaining the hydro-electrolytic balance. They can remove large amounts of water, heat and carbon dioxide.

Together with the bone system and the liver, the lungs are true tanks of blood, can keep a large amount for an unlimited, shorter or a very long time after the needs of the body. The same is done for the liver, but only for short periods of time for certain blood vessels. Bones that produce blood in their marrow can store large amounts of blood, and can also regenerate it so that the lungs form alongside the bone system in a true blood-capacitor reservoir, absolutely necessary for the human body. When the amount of blood and water in the body decreases, the body begins to age and lose energy from water and transported through the blood. In order to delay the human aging process, it is therefore absolutely necessary to keep both lungs healthy at maximum functional capacity as well as the bone system for a long time in our lives.

For centuries, traditional medicine systems around the world have used plants to treat respiratory diseases.

Even modern studies have recognized the efficacy of a plant in treating respiratory diseases, repairing lung damage, and improving lung function. They can be used as alternatives to drugs to solve lung problems. Onions and garlic remain two main active remedies for permanent maintenance of the lungs.

\section{ACKNOWLEDGEMENT}


DOI: 10.14807/ijmp.v12i8.957

This text was acknowledged and appreciated by Dr. Veturia CHIROIU Honorific member of Technical Sciences Academy of Romania (ASTR) PhD supervisor in Mechanical Engineering.

\section{REFERENCES}

Abdul-Razzak, K., Alzoubi, K., Abdo, S., \& Hananeh, W. (2012). High-dose vitamin C: Does it exacerbate the effect of psychosocial stress on liver? Biochemical and histological study, Experimental and Toxicologic Pathology, 64(4), 367-371

Ahmed, E., Omar, H., Elghaffar, S., Ragb, S., \& Nasser, A. (2011). The antioxidant activity of Vitamin C, DPPD and l-cysteine against Cisplatin-induced testicular oxidative damage in rats, Food and Chemical Toxicology, 49(5), 1115-1121

Ajith, T. A., Abhishek, G., Roshny, D., \& Sudheesh, N. P. (2009). Co-supplementation of single and multi doses of vitamins $\mathrm{C}$ and $\mathrm{E}$ ameliorates cisplatin-induced acute renal failure in mice, Experimental and Toxicologic Pathology, 61(1), 565-571

Alexander, C. A., \& Wang, L. (2018). Healthcare Driven by Big Data Analytics. Am. J. Eng. Applied Sci., 11(3), 1154-1163. DOI: 10.3844/ajeassp.2018.1154.1163

Aljohani, A., \& Desai, S. (2018). 3D Printing of Porous Scaffolds for Medical Applications. Am. J. Eng. Applied Sci., 11(3), 1076-1085. DOI: 10.3844/ajeassp.2018.1076.1085

Apicella, A., Aversa, R., \& Petrescu, F. I. T. (2018a). Hybrid Ceramo-Polymeric NanoDiamond Composites. Am. J. Eng. Applied Sci., 11(2), 766-782. DOI: 10.3844/ajeassp.2018.766.782

Apicella, A., Aversa, R., \& Petrescu, F. I. T. (2018b). Biomechanically Inspired Machines, Driven by Muscle Like Acting NiTi Alloys. Am. J. Eng. Applied Sci., 11(2), 809-829. DOI: 10.3844/ajeassp.2018.809.829

Apicella, A., Aversa, R., Tamburrino, F., \& Petrescu, F. I. T. (2018c). About the Internal Structure of a Bone and its Functional Role. Am. J. Eng. Applied Sci., 11(2), 914-931. DOI: 10.3844/ajeassp.2018.914.931

Armah, S. K. (2018). Stress Analysis of an Artificial Human Elbow Joint: Application of Finite Element Analysis. Am. J. Eng. Applied Sci., 11(1), 1-18. DOI:

10.3844/ajeassp.2018.1.18

Atasayar, S., Gürer-Orhan, H., Gürel, B., Girgin, G., \& Özgünes, H. (2009) Preventive effect of aminoguanidine compared to vitamin $\mathrm{E}$ and $\mathrm{C}$ on cisplatin-induced nephrotoxicity in rats, Experimental and Toxicologic Pathology, 61(1), 23-32

Aversa, R., Apicella, A., Tamburrino, F., \& Petrescu, F. I. T. (2018a). Mechanically Stimulated Osteoblast Cells Growth. Am. J. Eng. Applied Sci., 11(2), 1023-1036. DOI: 10.3844/ajeassp.2018.1023.1036

Aversa, R., Parcesepe, D., Tamburrino, F., Apicella, A., \& Petrescu, F. I. T. (2018b). Cold Crystallization Behavior of a Zr44-Ti11-Cu10-Ni10-Be25 Metal Glassy Alloy. Am. J. Eng. Applied Sci., 11(2), 1005-1022. DOI: 10.3844/ajeassp.2018.1005.1022

Aversa, R., Petrescu, R. V. V., Apicella, A., \& Petrescu, F. I. T. (2017a). Nano-diamond hybrid materials for structural biomedical application. Am. J. Biochem. Biotechnol., 13, 3441. DOI: 10.3844/ajbbsp.2017.34.41 
Aversa, R., Parcesepe, D., Petrescu, R. V. V., Berto, F., \& Chen, G. (2017b). Process ability of bulk metallic glasses. Am. J. Applied Sci., 14, 294-301. DOI:

10.3844/ajassp.2017.294.301

Aversa, R., Petrescu, F. I. T., Petrescu, R. V., \& Apicella, A. (2016a). Biomimetic FEA bone modeling for customized hybrid biological prostheses development. Am. J. Applied Sci., 13, 1060-1067. DOI: 10.3844/ajassp.2016.1060.1067

Aversa, R., Parcesepe, D., Petrescu, R. V., Chen, G., \& Petrescu, F. I. T. (2016b). Glassy amorphous metal injection molded induced morphological defects. Am. J. Applied Sci., 13, 1476-1482. DOI: 10.3844/ajassp.2016.1476.1482

Aversa, R., Tamburrino, F., Petrescu, R. V., Petrescu, F. I. T., \& Artur M. (2016c). Biomechanically inspired shape memory effect machines driven by muscle like acting NiTi alloys. Am. J. Applied Sci., 13, 1264-1271. DOI: 10.3844/ajassp.2016.1264.1271

Aversa, R., Buzea, E. M.Petrescu, R. V., Apicella, A., \& Neacsa, M. (2016d). Present a mechatronic system having able to determine the concentration of carotenoids. Am. J. Eng. Applied Sci., 9, 1106-1111. DOI: 10.3844/ajeassp.2016.1106.1111

Aversa, R., Petrescu, R. V., Sorrentino, R., Petrescu, F. I. T., \& Apicella, A. (2016e). Hybrid ceramo-polymeric nanocomposite for biomimetic scaffolds design and preparation. Am. J.

Eng. Applied Sci., 9, 1096-1105. DOI: 10.3844/ajeassp.2016.1096.1105

Aversa, R., Perrotta, V., Petrescu, R. V., Misiano, C., \& Petrescu, F. I. T. (2016f). From structural colors to super-hydrophobicity and achromatic transparent protective coatings: Ion plating plasma assisted $\mathrm{TiO}_{2}$ and $\mathrm{SiO}_{2}$ nano-film deposition. Am. J. Eng. Applied Sci., 9, 1037-1045. DOI: 10.3844/ajeassp.2016.1037.1045

Aversa, R., Petrescu, R. V., Petrescu, F. I. T., \& Apicella, A. (2016g). Biomimetic and evolutionary design driven innovation in sustainable products development. Am. J. Eng. Applied Sci., 9, 1027-1036. DOI: 10.3844/ajeassp.2016.1027.1036

Aversa, R., Petrescu, R. V., Apicella, A., \& Petrescu, F. I. T. (2016h). Mitochondria are naturally micro robots - a review. Am. J. Eng. Applied Sci., 9, 991-1002. DOI:

10.3844/ajeassp.2016.991.1002

Aversa, R., Petrescu, R. V., Apicella, A., \& Petrescu, F. I. T. (2016i). We are addicted to vitamins C and E-A review. Am. J. Eng. Applied Sci., 9, 1003-1018. DOI: 10.3844/ajeassp.2016.1003.1018

Aversa, R., Petrescu, R. V., Apicella, A., \& Petrescu, F. I. T. (2016j). Physiologic human fluids and swelling behavior of hydrophilic biocompatible hybrid ceramo-polymeric materials. Am. J. Eng. Applied Sci., 9, 962-972. DOI: 10.3844/ajeassp.2016.962.972

Aversa, R., Petrescu, R. V., Apicella, A., \& Petrescu, F. I. T. (2016k). One can slow down the aging through antioxidants. Am. J. Eng. Applied Sci., 9, 1112-1126. DOI:

10.3844/ajeassp.2016.1112.1126

Aversa, R., Petrescu, R. V., Apicella, A., \& Petrescu, F. I. T. (2016l). About homeopathy or «Similia Similibus Curentur». Am. J. Eng. Applied Sci., 9, 1164-1172. DOI: 10.3844/ajeassp.2016.1164.1172

Aversa, R., Petrescu, R. V., Apicella, A., \& Petrescu, F. I. T. (2016m). The basic elements of life's. Am. J. Eng. Applied Sci., 9, 1189-1197. DOI: 10.3844/ajeassp.2016.1189.1197 
Aversa, R., Petrescu, F. I. T., Petrescu, R. V., \& Apicella, A. (2016n). Flexible stem trabecular prostheses. Am. J. Eng. Applied Sci., 9, 1213-1221. DOI:

10.3844/ajeassp.2016.1213.122

Babaev, V. R., Li, L., Shah, S., Fazio, S., Linton, M. F., May, J. M. (2010). Combined Vitamin C and Vitamin E Deficiency Worsens Early Atherosclerosis in ApoE-Deficient Mice, Arteriosclerosis, thrombosis, and vascular biology, 30(9), 1751-1757

Buzea, E., Petrescu, F. L., Nănuţ, L., Nan, C., \& Neacşa, M. (2015). Mechatronic System to Determine the Concentration of Carotenoids, Analele Univers. Craiova Biologie

Horticultura Tehn. Prel. Prod. Agr. Ing. Med., 20(1), 371-376

Choudhury, A., \& Greene, C. M. (2018). Identification of Cancer: Mesothelioma's Disease Using Logistic Regression and Association Rule. Am. J. Eng. Applied Sci., 11(4).

Choudhury, A. (2018). Evaluating Patient Readmission Risk: A Predictive Analytics Approach. Am. J. Eng. Applied Sci., 11(4).

Covic, M., Covic, A., Tatomir, P. G., Segall, L. (2007). Manual de nefrologie, Polirom Publisher, 448 pages, ISBN: 978-973-46-0672-6

El-Gendy, K. S., Aly, N. M., Mahmoud, F. H., Kenawy, A., El-Sebae, A. K. (2009). The role of vitamin $\mathrm{C}$ as antioxidant in protection of oxidative stress induced by imidacloprid, Food Chem Toxicol, 48(1), 215-221

Enstrom, J., (2014). Food and You: Feeding The World With Modern Agricultural Biotechnology, American Council on Science and Health. Retrieved from: http://acsh.org/2014/03/food-feeding-world-modern-agricultural-biotechnology-2/

Ha, H-L., Shin, H-J., Feitelson, M. A., \& Yu, D-Y. (2010). Oxidative stress and antioxidants in hepatic pathogenesis, World Journal of Gastroenterology: WJG., 16(48), 6035-6043

Hansen, S. N., Tveden-Nyborg, P., \& Lykkesfeldt, J. (2014). Does vitamin C deficiency affect cognitive development and function? Nutrients., 6(9), 3818-3846

Hickey, S., \& Roberts H. (2007). The Cancer Breakthrough, 96 pages, ISBN 9781430323006 Kunutsor, S., Kurl, S., Zaccardi, F., Laukkanen, J. (2016). Baseline and long-term fibrinogen levels and risk of sudden cardiac death: A new prospective study and meta-analysis, Atherosclerosis, 245, 171-180

Marquetti, I., \& Desai, S. (2018). Adsorption Behavior of Bone Morphogenetic Protein-2 on a Graphite Substrate for Biomedical Applications. Am. J. Eng. Applied Sci., 11(2), 10371044. DOI: 10.3844/ajeassp.2018.1037.1044

Petrescu, F. L., Buzea, E., Nănuţ, L., Neacşa, M., \& Nan, C. (2015). The Role of Antioxidants in Slowing Aging of Skin in a Human, Analele Univers. Craiova Biologie Horticultura Tehn. Prel. Prod. Agr. Ing. Med., 20(1), 567-574

Petrescu, G. (2008). Essential in Physiology, Vol. I., Junimea Publishing House, Iasi. Petrescu, G. (2009). Essential in Physiology, Vol. II., UMF Publishing House, Iasi.

Rath, M., \& Pauling L. (1990). Hypothesis: lipoprotein(a) is a surrogate for ascorbate, Proc Natl Acad Sci U S A, 87(16):6204-6207

Rath, M. (2003). Why Animals Don't Get Heart Attacks. . . but People Do!, MR Publishing, Inc., Fremont, CA, USA, Edition: 4th, Fourth, 319 pages, ISBN 13: 978-0-9679546-8-4 
Ravnskov, U. (2009). Fat and Cholesterol are Good for You, 244 pages, Publisher: GB Publishing, English, ISBN-13: 978-9197555388

Tamburrino, F., Apicella, A., Aversa, R., \& Petrescu, F. I. T. (2018). Advanced Manufacturing for Novel Materials in Industrial Design Applications. Am. J. Eng. Applied Sci., 11(2):932-972. DOI: 10.3844/ajeassp.2018.932.972

Wilk, J., Sanders, G., Marks, S., Paolicelli, S. A., Dicaprio, M., \& Bucinell, R. (2017). The Optimization of a Porous Ti6Al4V Bone Construct Using Additive Manufacturing. Am. J. Eng. Applied Sci., 10(1), 13-19. DOI: 10.3844/ajeassp.2017.13.19

Willis, G. C. (1953) An experimental study of the intimal ground substance in atherosclerosis, Can Med Assoc J., 69, 17-22

Willis, G. C., Light A. W., \& Gow W. S. (1954) Serial Arteriography in Atherosclerosis in Human Beings, Can Med Assoc J., 71, 562-568

Willis, G. C. (1957) The reversibility of atherosclerosis, Can Med Assoc J., 77, 106-108 